\title{
Evaluation of resistance to Tomato severe rugose virus (ToSRV) in Capsicum spp. genotypes
}

\author{
Kelly C.G. Rocha ${ }^{1}$, Julio M. Marubayashi ${ }^{1}$, Tatiana Mituti ${ }^{1}$, Ricardo Gioria ${ }^{2}$, Rômulo F. Kobori' ${ }^{2}$, Arlete \\ M.T. Melo ${ }^{3}$, Marcelo A. Pavan' ${ }^{1} \&$ Renate Krause-Sakate ${ }^{1}$
}

${ }^{1}$ Departamento de Produção Vegetal, Faculdade de Ciências Agronômicas, Unesp, Rua José Barbosa de Barros, ${ }^{\circ} 1780$, 18603-970, Botucatu, SP, Brazil; ${ }^{2}$ Sakata Seed Sudamérica, Cx. Postal 427, 12906-840, Bragança Paulista, SP, Brazil; ${ }^{3}$ Instituto Agronômico, Cx. Postal 28, 13012-970, Campinas, SP, Brazil

Author for correspondence: Kelly C.G. Rocha, e-mail: kellygoncales@gmail.com

\begin{abstract}
Tomato severe rugose virus (ToSRV) is the predominant species of begomovirus in São Paulo State, Brazil, and infects primarily tomato and pepper plants. There is no information about genetic resistance of pepper to this virus, so in this work the reaction of 29 genotypes of Capsicum spp. was evaluated by inoculation of two ToSRV isolates: ToSRV-Sk (isolated from a tomato plant) and ToSRV-PJU (isolated from a pepper plant). For both isolates, two C. annuun genotypes (Catarino Cascabel - México and Silver) showed no symptoms 30 days after inoculation (d.a.i). In a second experiment, these two genotypes were evaluated for 150 d.a.i and, again, no symptoms could be observed. However, the virus was detected by RCA-PCR, indicating that both genotypes are susceptible, but less affected by ToSRV infection. Catarino Cascabel - México and Silver can be indicated for use in breeding programs for resistance of pepper to ToSRV.

Key words: Bemisia tabaci, chili peper, geminivirus, tolerance, sweet pepper.
\end{abstract}

\section{INTRODUCTION}

The sweet pepper (Capsicum annuum L.) is one of the ten most important vegetables cultivated in Brazil, consumed in natura and also used in the food industry. Widespread damage by geminiviruses has caused low yields of peppers in some crop production areas in the world, causing serious economic impacts. Therefore, special attention has been given to the genus Begomovirus (family Geminiviridae) (Navas-Castillo et al., 2011). Members of this genus have a circular single-stranded DNA (ssDNA) genome encapsidated in twinned icosahedral (geminate) virions. Transmission by natural means is through the whitefly Bemisia tabaci Gen. (Hemiptera: Aleyrodidae) (Stanley et al., 2005; Navas-Castillo et al., 2011).

Since the first report of begomoviruses in pepper in Brazil (Lima et al., 2001), B. tabaci belonging to the Middle East-Asia Minor 1 group, which includes the invasive populations of the commonly known B biotype (Dinsdale et al., 2010), has been frequently found in this crop, contributing to an increase in the incidence of these viruses, especially Tomato severe rugose virus (ToSRV), prevalent in São Paulo state (Nozaki et al., 2006; Rocha et al., 2010; Rocha et al., 2011) and widespread in Brazil (Fernandes et al., 2008). Brazil is considered one of the major diversity centers of the neotropical bipartite begomovirus cluster (Fernandes et al., 2008). In other parts of the world, at least fifteen different begomovirus species have been described infecting Capsicum spp. (Fauquet et al., 2008), but none of them has been detected so far in Brazil. Until now only
ToSRV and Tomato yellow vein streak virus (ToYVSV) have been found infecting Capsicum spp. in this country (Nozaki et al., 2006).

Plants of Capsicum infected by ToSRV show yellow mosaic and leaf distortion (Bezerra et al., 2006), yellowing of veins, chlorotic mottling and reduction of plant growth (Rocha et al., 2010).

In a pepper breeding program, it is essential to characterize the available germplasm in order to develop pepper varieties resistant to begomoviruses. Due to the scarce information on resistance of Capsicum spp. to begomoviruses, in this study we evaluated 29 genotypes of Capsicum spp. for ToSRV resistance.

\section{MATERIAL AND METHODS}

Two ToSRV isolates were used, one from Capsicum annuum (ToSRV-PJU) obtained by Nozaki (2007) and one from tomato plants (ToSRV-Sk) provided by Sakata Seed Sudamerica Company. Both isolates were maintained separately on tomato plants of Santa Clara cultivar to avoid contamination of the isolates.

The identity of both isolates of ToSRV was confirmed via partial sequencing of the coat protein present in the DNA-A component. Tomato plants infected with ToSRV-Sk isolate showed stunting, severe leaf deformation and yellowing, while those infected with ToSRV-PJU isolate showed vein clearing and mild leaf mosaic. 
In the first trial 19 genotypes of Capsicum spp. available in the germplasm bank of the Escola Superior de Agricultura "Luiz de Queiroz" (ESALQ) and of the Instituto Agronômico de Campinas (IAC), and 10 commercial genotypes were evaluated for their reaction to ToSRV-Sk and ToSRV-PJU (Table 1). The sowing of 10 plants of each genotype was done in expanded Styrofoam trays with 220 cells containing commercial substrate. The genotypes were divided into two trays each containing also tomato cultivar Santa Clara as a susceptible control. Each tray was placed in a cage. The seedlings were maintained in a greenhouse and were whitefly inoculated with the virus isolates 30 days after sowing.

Non-viruliferous B. tabaci collected on sweet pepper plants were maintained in a greenhouse with anti insect nets, on collard green (Brassica oleraceae L. var. acephala) and soybean (Glycine max) plants, which are non-host of ToSRV species. The whitefly species was identified by using PCRRFLP analysis and sequencing the mtCOI gene (Rocha et al., 2011). For ToSRV-PJU transmission, adult insects were collected from collard green and soybean plants with the aid of a glass tube mouth aspirator. The insects were transferred to small cages containing branches of tomato plants infected with ToSRV-PJU. Approximately 1,000 insects were placed in each cage, which were kept in a dark room maintained at $30^{\circ} \mathrm{C}$ for an acquisition access period (AAP) of 24 hours. Following the AAP, around 5000 whiteflies were transferred to the cages containing 80 seedlings per tray (average of 50 insects per seedling) for an inoculation access period (IAP) of seven days. Following the IAP, the plants were sprayed with insecticides (imidacloprid after IAP and acefate plus buprofezin one week later, always using the manufacturer's recommended dosage) to eliminate the whitefly adults, nymphs, and eggs. The plants were kept in a greenhouse at 25 to $30^{\circ} \mathrm{C}$ for a period of 30 days.

For transmission of the ToSRV-Sk isolate, whiteflies were reared on infected tomato plants, in an air-conditioned room $\left(28^{\circ} \mathrm{C}\right.$ and $\left.80 \% \mathrm{RH}\right)$. The polystyrene trays containing pepper seedlings were placed in the same room and the vector population was maintained on an average of 50 insects per pepper seedling. The IAP was of seven days, after which the seedlings were exposed to the same treatments and conditions described for inoculation of the ToSRV-PJU isolate. For both isolates, tomato plants from the cultivar Santa Clara were inoculated in the same conditions as positive control.

Symptom and the virus presence by PCR analysis was evaluated 30 days after inoculation (d.a.i.). Total DNA was extracted from the 10 plants of each genotype following the protocol described by Dellaporta et al. (1983). The PCR Master Mix (Promega) pre-mix and the oligonucleotide pair GemiA1202s 5' TGG TAG ACT CTG CTC GCG G 3' (sense) and GemiA1876a 5' CTC TTT CAC TAG CGT ACC G 3' (antisense) (Nozaki, 2007), which are directed to part of the gene that encodes the Rep (AC1) and the Trap (AC2) genes, were used in the PCR reaction. These primers are useful for detection of both isolates. The program consisted of initial denaturation at $95^{\circ} \mathrm{C}$ for 2 minutes, followed by 40 cycles at $94^{\circ} \mathrm{C}$ for 40 seconds, annealing at $54^{\circ} \mathrm{C}$ for 1 minute, and extension to $72^{\circ} \mathrm{C}$ for 1 minute, with a final extension step at $72^{\circ} \mathrm{C}$ for 10 minutes. The amplified ( $\sim 670 \mathrm{bp})$ DNA fragment was submitted to gel electrophoresis in $0.8 \%$ agarose and stained with ethidium bromide.

Due to the promising results obtained in the first trial for the accessions Catarino Cascabel - México and Silver, fifteen plants of each genotype were re-inoculated with just the more aggressive isolate, ToSRV-Sk, following the same conditions previously described and evaluated for 150 d.a.i. Santa Clara tomato cultivar and C. annuum (8752-1) were used as susceptible controls. All seedlings were transplanted individually into a 5-liter plastic pot and maintained into a fertirrigation system.

The presence of symptoms and virus was evaluated during the period of 150 days. Total DNA from the leaf tissue of the apex of the plant was extracted using the same protocol previously described. Molecular analysis was performed by rolling circle amplification (RCA), a more sensitive method suitable for begomovirus detection (Inoue-Nagata et al., 2004; Haible et al., 2006), followed by PCR amplification of part of the DNA-A component with the same primers used previously, Gemi1202s/Gemi1876a. PCR amplification products were analyzed in agarose-gel electrophoresis stained with SYBR Safe (Invitrogen).

\section{RESULTS AND DISCUSSION}

All tomato plants from cultivar Santa Clara used as susceptible control were infected by both isolates, indicating that the whiteflies were viruliferous and the virus infective. The appearance of symptoms on inoculated plants caused by ToSRV-Sk occurred earlier than on those inoculated with isolate ToSRV-PJU. For ToSRV-Sk and ToSRV-PJU isolates, 25 and 14 accessions were infected, respectively, showing symptoms of leaf distortion, wrinkled leaves, mosaic, vein clearing and reduction in plant growth (Table 1). The ToSRV-Sk isolate was able to infect more plants and more pepper cultivars than the pepper isolate ToSRV-PJU. There are two possible explanations for this result: the first is the higher virulence of the -Sk isolate, which may be well adapted to pepper plants; the second is an influence of the inoculation method which can be related to the differences in the infection rate. In the inoculation of the PJU isolate, viruliferous whiteflies were produced by feeding the insects in detached infected leaves and in dark conditions, whereas those of the Sk isolate were reared on infected plants. If the virus acquisition was hampered by this condition it is reasonable to assume that fewer virus particles were available for inoculation of these plants when the PJU isolate was used, and thus fewer plants were infected. However, it is noteworthy that in each unit tray inoculated with the PJU isolate, all Santa Clara tomato 
plants showed symptoms, indicating that the whiteflies were viruliferous and capable of transmitting the virus.

Due to the lower number of pepper plants infected with the PJU isolate, the analysis was made mainly based on the inoculation of the Sk isolate. Out of the 29 tested accessions of Capsicum, four did not display visual symptoms for the Sk isolate: Capsicum annum Silver, C. annum IAC -545, C. annum Pimenta Serrano IAC - 1129 and C. annum Catarino Cascabel - México (Table 1). In this first experiment the virus could be detected by PCR on the first three genotypes. Others genotypes of $C$. annuum (IAC-Colombia\#12 and Pimenta Filipinas \#124) and C. frutescens (IAC-822) presented a low number of plants infected with Sk isolate, but the infected plants showed some symptoms. Most chili peppers tested, composed of three species of C. annuum (Dinamo, JalapeñoMonte alto, Pimenta Picante), C. baccatum (Dedo-de-moça, Pimenta Guarnica\#243) and C. chinense (PI 159236 IAC-984, Pimenta-Argentina, Pimenta Colombia, Pimenta Habanero BG592), showed high susceptibility to -Sk with a large number of plants infected (Table 1).

In the first experiment, symptoms caused by ToSRV-Sk could be observed in all commercial cultivars of chili and sweet pepper, except for Silver and Catarino Cascabel. To better evaluate the asymptomatic response, these two genotypes were re-inoculated with ToSRV-Sk and the presence of virus checked by RCA-PCR. The virus was detected on both genotypes, 12 positive plants for Catarino Cascabel and 12 positive plants for Silver, from

TABLE 1 - Results of the inoculation of two ToSRV isolates on Capsicum spp. accessions, based on symptom expression and PCR detection

\begin{tabular}{|c|c|c|c|c|c|}
\hline \multirow[t]{2}{*}{ Plant species } & \multirow[t]{2}{*}{ Accessions/Source } & \multicolumn{2}{|c|}{ ToSRV-Sk } & \multicolumn{2}{|c|}{ ToSRV-PJU } \\
\hline & & Inf/Inoc & Symptoms & Inf/Inoc & Symptoms \\
\hline Capsicum annuит & Paloma (Commercial) & $5 / 10$ & $\mathrm{M} / \mathrm{VC} / \mathrm{LD} / \mathrm{RS}$ & $10 / 10$ & $\mathrm{M} / \mathrm{VC}$ \\
\hline Capsicum annuum & Martha R (Commercial) & $7 / 10$ & $\mathrm{VC} / \mathrm{W}$ & $5 / 10$ & $\mathrm{M} / \mathrm{VC}$ \\
\hline Capsicum аппиит & Amarelo - Satrapo (Commercial) & $7 / 10$ & $\mathrm{MM} / \mathrm{VC} / \mathrm{RS}$ & $* * *$ & $* * *$ \\
\hline Capsicum annuит & Hebron (Commercial) & $10 / 10$ & $\mathrm{CS} / \mathrm{RS} / \mathrm{MM} / \mathrm{VC}$ & $5 / 10$ & NS \\
\hline Capsicum annuum & Itamara (Commercial) & $9 / 10$ & $\mathrm{VC} / \mathrm{MM} / \mathrm{W}$ & $8 / 10$ & $\mathrm{M} / \mathrm{VC}$ \\
\hline Capsicum annuum & Pimenta Dínamo (Commercial) & $9 / 10$ & $\mathrm{VC} / \mathrm{M}$ & $2 / 10$ & $\mathrm{M} / \mathrm{VC}$ \\
\hline Capsicum annuит & Máximos (Commercial) & $7 / 10$ & LC & $3 / 10$ & $\mathrm{VC}$ \\
\hline Capsicum annuиm & Jalapeño (Commercial) & $5 / 10$ & $\mathrm{VC} / \mathrm{M}$ & $4 / 10$ & $\mathrm{M} / \mathrm{VC}$ \\
\hline Capsicum аппиит & Silver (Commercial) & $4 / 10$ & NS & $0 / 10$ & NS \\
\hline Capsicum аппиит & Magali R (Commercial) & $7 / 10$ & $\mathrm{VC} / \mathrm{W}$ & $4 / 10$ & $\mathrm{M} / \mathrm{VC}$ \\
\hline Capsicum аппиит & IAC $-545($ IAC) & $8 / 10$ & NS & $5 / 10$ & $\mathrm{~W} / \mathrm{M}$ \\
\hline Capsicum аппиит & IAC 11-8-1 (IAC) & $6 / 10$ & $\mathrm{VC} / \mathrm{W}$ & $6 / 10$ & $\mathrm{~W} / \mathrm{M}$ \\
\hline Capsicum anпuиm & IAC 21-4-2 (IAC) & $5 / 10$ & $\mathrm{RS} / \mathrm{LD}$ & $3 / 10$ & $\mathrm{MM}$ \\
\hline Capsicum frutescens & Pimenta malagueta IAC-822 (IAC) & $3 / 10$ & $\mathrm{VC}$ & $7 / 10$ & $\mathrm{MM}$ \\
\hline Capsicum аппиит & Criollo de Morellos 334 IAC-982 (IAC) & $5 / 10$ & $\mathrm{VC}$ & $3 / 10$ & M \\
\hline Capsicum anпuит & Pimenta Serrano IAC - 1129 (IAC) & $3 / 10$ & NS & $3 / 10$ & $\mathrm{MM}$ \\
\hline Capsicum baccatum & Dedo-de-moça (ESALQ/USP) & $8 / 10$ & $\mathrm{M} / \mathrm{W}$ & $10 / 10$ & $\mathrm{~W} / \mathrm{LD}$ \\
\hline Capsicum chinense & Murupi Pimenta de cheiro IAC-1243 (IAC) & $5 / 10$ & RS & $0 / 10$ & NS \\
\hline Capsicum chinense & PI 159236 IAC-984 (IAC) & $9 / 10$ & $\mathrm{CS}$ & $0 / 10$ & NS \\
\hline Capsicum frutescens & Malaguetão IAC-1077 (IAC) & $6 / 10$ & $\mathrm{CS} / \mathrm{VC}$ & $0 / 10$ & NS \\
\hline Capsicum chinense & Pimenta - Argentina (ESALQ/USP) & $6 / 10$ & $\mathrm{VC} / \mathrm{M}$ & $0 / 10$ & NS \\
\hline Capsicum chinense & Pimenta - Colômbia (ESALQ/USP) & $8 / 10$ & $\mathrm{VC}$ & $0 / 10$ & NS \\
\hline Capsicum annuum & Jalapeño - Monte Alto (ESALQ/USP) & $8 / 10$ & $\mathrm{VC} / \mathrm{CP} / \mathrm{M}$ & $0 / 10$ & NS \\
\hline Capsicum anпuиm & Pimenta picante (ESALQ/USP) & $10 / 10$ & $\mathrm{M} / \mathrm{LY}$ & $0 / 10$ & NS \\
\hline Capsicum baccatum & Pimenta Guarnica \#243 - Bolívia (ESALQ/USP) & $10 / 10$ & $\mathrm{M} / \mathrm{RS} / \mathrm{LD}$ & $0 / 10$ & NS \\
\hline Capsicum chinense & Pimenta Habanero BG 592 (ESALQ/USP) & $10 / 10$ & $\mathrm{M} / \mathrm{RS} / \mathrm{LD}$ & $1 / 10$ & NS \\
\hline Capsicum annuum & IAC Colômbia \# 12 (ESALQ/USP) & $2 / 10$ & $\mathrm{MM} / \mathrm{VC}$ & $0 / 10$ & NS \\
\hline Capsicum annuum & Pimenta Filipinas \# 124 (ESALQ/USP) & $3 / 10$ & $\mathrm{LD} / \mathrm{VC} / \mathrm{CS}$ & $0 / 10$ & NS \\
\hline Capsicum annuum & Catarino Cascabel - México (ESALQ/USP) & $0 / 10$ & NS & $0 / 10$ & NS \\
\hline
\end{tabular}

***Not inoculated; NS: no symptoms; LY: leaf yellowing; LD: leaf distortion; W: wrinkled leaves; YB: yellow blotches; M: mosaic; MM: mild mosaic; VC: vein clearing; RS: reduction in plant growth; CS: chlorotic spots; LC: leaf curling. NPInf= number of infected plants positive for PCR, NPInoc $=$ number of plants inoculated. 
15 inoculated plants, but all plants remained asymptomatic during the 150 days of evaluation. A great variability was observed for the detection of the virus in these two genotypes during the period evaluated (Table 2). A higher number of RCA-PCR positive plants were detected at 90 d.a.i. (Table 2). This phase coincided with the time of fruit production and first harvest. It is possible that the virus replication and movement increased, due to the high demand for metabolites, facilitating their detection. A considerable reduction in the detection of virus was observed at 150 d.a.i. For Capsicum 8752-1 plants, highly susceptible to ToSRV-Sk and used as a positive control, the virus could be detected in all stages of plant development.

Replication and movement are two important processes for viral infection (Gárcia-Neria and Bustamante, 2011) and are frequently affected in plants displaying resistance to viruses (Fraser, 1990; Hull, 1991). Accession BG-3821 of $C$. chinense Jacq. is reported as resistant to Pepper golden mosaic virus (PepGMV) and Pepper huasteco yellow vein virus (PHYVV) (Anaya-López et al., 2003). The replication of PepGMV in protoplast of resistant plants is approximately $70 \%$ lower when compared with the levels observed in protoplast of susceptible plants, and in addition viral movement is less efficient in resistant plants (García-Neria and Rivera-Bustamante, 2011). Systemic acquired resistance (SAR) is one the most conserved mechanisms of resistance to several pathogens, including viruses, and involves reactive oxygen species, salicylic acid (SA) accumulation and the induction of pathogenesisrelated (PR) genes (Chivasa et al., 1997, Vlot et al, 2009).
The resistance to PepGMV in C. chinense involves higher accumulation of SA and reactive oxygen species (GarcíaNeria and Rivera-Bustamante, 2011). Characterizing the resistance trait of Catarino Cascabel and Silver to ToSRV$\mathrm{Sk}$ is important information that could help to determine useful markers to support breeding processes.

Since no resistance to ToSRV has been found in the commercial pepper cultivars, and infected Capsicum plants with ToSRV showed a marked reduction in the number of fruit and plant growth compared with healthy plants (Rocha et al., 2012), searching for resistance sources to ToSRV is an ongoing process and one of the steps for effective disease control. The genotype Silver (C. annuum) is a commercial hybrid, used in Brazil as a rootstock for resistance to Phytophthora capsici and nematodes (Meloidogyne javanica, M. incognita races 1, 2, 3 and 4) (Oliveira et al., 2009), while Catarino Cascabel - Mexico (C. annuum) is a commercial material used in Mexico, much appreciated in cooking and consumed fresh or dry (Rodrigues et al., 2011).

Diseases caused by begomoviruses have emerged as an important problem for pepper in other countries (Quiñones et al., 2002; Fauquet et al., 2008; García-Neria \& Rivera-Bustamante, 2011). In Brazil, so far begomovirus does not limit the cultivation of sweet pepper, but it is becoming more common to find greenhouses with peppers infested with whiteflies. This indicates adaptation of the insect to the crop, and serves as a warning that we could have problems with begomovirus in Capsicum in the near future. Catarino Cascabel has no market value for use in

TABLE 2 - Detection of Tomato severe rugose virus-Sk by RCA-PCR in plants of the accessions Catarino Cascabel and Silver, up to 150 days post-inoculation with Bemisia tabaci. Ten plants of susceptible Capsicum annuum 8752-1 were infected with ToSRV-Sk and the virus was detected at different time points during the period analyzed

\begin{tabular}{|c|c|c|c|c|c|c|c|c|c|c|}
\hline \multicolumn{11}{|c|}{ Days post-inoculation } \\
\hline \multirow[b]{3}{*}{$\begin{array}{l}\text { Individual } \\
\text { plants } \\
\text { inoculated } \\
\text { with } \\
\text { ToSRV }\end{array}$} & \multicolumn{2}{|c|}{30} & \multirow{2}{*}{\multicolumn{2}{|c|}{60}} & \multicolumn{2}{|c|}{90} & \multicolumn{2}{|c|}{120} & \multicolumn{2}{|c|}{150} \\
\hline & & & & & \multicolumn{2}{|c|}{ Accessions } & & & & \\
\hline & $\begin{array}{l}\text { Catarino } \\
\text { Cascabel }\end{array}$ & Silver & $\begin{array}{l}\text { Catarino } \\
\text { Cascabel }\end{array}$ & Silver & $\begin{array}{l}\text { Catarino } \\
\text { Cascabel }\end{array}$ & Silver & $\begin{array}{l}\text { Catarino } \\
\text { Cascabel }\end{array}$ & Silver & $\begin{array}{l}\text { Catarino } \\
\text { Cascabel }\end{array}$ & Silver \\
\hline 1 & & & & & + & + & & & & \\
\hline 2 & & + & + & & + & & + & + & & + \\
\hline 3 & + & + & & & + & + & & + & & + \\
\hline 4 & & + & + & & & + & & & & \\
\hline 5 & & & + & + & + & & & & & \\
\hline 6 & + & & & & + & + & + & & & \\
\hline 7 & & & & & & + & & & & + \\
\hline 8 & & & & & + & & & + & & \\
\hline 9 & & & + & & + & + & & & & \\
\hline 10 & + & & & & + & + & + & + & & + \\
\hline 11 & & & & & + & + & + & + & + & \\
\hline 12 & & & + & & + & + & + & & & \\
\hline 13 & & & & + & & + & + & & & \\
\hline 14 & + & & + & & + & + & + & & + & \\
\hline 15 & & & & & + & + & & + & & \\
\hline
\end{tabular}


K.C.G. Rocha et al.

Brazil, but like Silver, this cultivar can be used as a source for breeding and mapping resistant genes to ToSRV in $C$. annuит.

\section{ACKNOWLEDGEMENTS}

The authors are grateful to Sakata Seed Sudamerica Company for research support and Instituto Agronômico de Campinas - IAC and Dr. Cyro Paulino da Costa for providing the seeds used in this study.

\section{REFERENCES}

Anaya López JL, Torres Pacheco I, González Chavira M, PonsHernández JL, Guevara-González RG, Muñoz-Sánchez CI; Guevara-Olvera L, Rivera-Bustamante RF, Hernández-Verdugo S (2003) Resistanse to geminivirus mixed infections in Mexican wild peppers. HortScience 38:251-255.

Bezerra-Agasie IC, Ferreira GB, Ávila A.C., Inoue-Nagata AK (2006) First report of Tomato severe rugose virus in chili pepper in Brazil. Plant Disease 90:114.

Chivasa S, Murphy AM, Naylor M, Carr JP (1997) Salicylic acid interferes with Tobacco mosaic virus replication via a novel salicylhy-droxamic acid-sensitive mechanism. Plant Cell 5:547557.

Dellaporta SL, Woods J, Hicks JB (1983) A plant DNA minipreparation, version II. Plant Molecular Biology Reporter 1:19-21.

Fauquet CM, Briddon RW, Brown JK, Moriones E, Stanley J, Zerbini FM, Zhou X (2008) Geminivirus strain demarcation and nomenclature. Archives of Virology 153: 783-821.

Fernandes FR, Albuquerque LC, Giordano LB, Boiteux LS, Ávila AC, Inoue-Nagata AK (2008) Diversity and prevalence of Brazilian bipartite begomovirus species associated to tomatoes. Virus Genes 36:251-258.

Fraser RSS (1990) The genetics of resistance to plant viruses. Annual Review of Phytopathology 28:179-200.

García-Neria MA, Bustamante RFR (2011) Characterization of geminivirus resistance in an accession of Capsicum chinense Jacq. Molecular Plant-Microbe Interactions 24:172-182.

Godinez-Hernández Y, Anaya-López JL, Díaz-Plaza R, GonzálezChavira M, Torres-Pacheco I (2001) Characterization of resistance to pepper huasteco geminivirus in chili peppers (Capsicum chinense) from Yucatán, México. HortScience 36:139-142.

Haible D, Kober S, Jeske H (2006) Rolling circle amplification revolutionizes diagnosis and genomics of geminiviruses. Journal of Virological Methods 135:9-16.

Hernandez-Verdugo S, Guevara-Gonzalez RG, RiveraBustamante RF, Oyama K (2001) Screening wild plants of Capsicum annuum for resistance to pepper huasteco virus (PHV): Presence of viral DNA and differentiation among populations. Euphytica 122:31-36.
Hull R (1991) The movement of viruses in plants. Annual Review of Phytopathology 27:213-240.

Inoue-Nagata AK, Albuquerque LC, Rocha WB, Nagata T (2004) A simple method for cloning the complete begomovirus genome using the bacteriophage phi29 DNA polymerase. Journal of Virological Methods 116:209-211.

Lima MF, Bezerra IC, Ribeiro SG, Ávila AC (2001) Distribuição de geminivírus nas culturas do tomate e pimentão em doze municípios do Submédio do Vale de São Francisco. Fitopatologia Brasileira 26:81-85.

Nozaki DN2007. Estudos biológicos e moleculares de begomovírus infectando pimentão (Capsicum annuum) no Estado de São Paulo. PhD Dissertation, Universidade Estadual Paulista. Botucatu SP.

Nozaki DN, Krause-Sakate R., Hasegawa JM, Cézar MA, Dziuba PH, Pavan MA (2006) First report of Tomato severe rugose virus infecting pepper plants in Brazil. Fitopatologia Brasileira 31:321321.

Oliveira CD, BrazLT, Santos JM, Banzatto DA, Oliveira PR (2009) Resistência de pimentas a nematóides de galha e compatibilidade enxerto/porta-enxerto entre híbridos de pimentão e pimentas. Horticultura Brasileira 27: 520-526.

Peixoto JR, Ramos RS, Faria B, Silva CM, Angelis B (1999) Avaliação de genótipos de pimentão no período de inverno, em Araguari, MG. Pesquisa Agropecuária Brasileira 34:1865-1869.

Quiñones M, Fonseca D, Acotto GP, Martínez Y (2002) Viral infection associated with the presence of Begomoviruses in pepper plants in Cuba. Plant Disease 86:73.

Rocha KCG, Marubayashi JM, Navas-Castillo J, Pavan MA, Krause-Sakate R (2010) Ocorrência e variabilidade genética do Tomato severe rugose virus em tomateiro e pimentão no Estado de São Paulo. Summa Phytopathologica 36:222-227.

Rocha KCG, Marubayashi JM, Navas-Castillo J, Yuki VA, Wilcken CF, Pavan MA, Krause-Sakate R (2011) Only the B biotype of Bemisia tabaci is present on vegetables in São Paulo state, Brazil. Scientia Agricola 68:120-123.

Rocha KCG, Krause-Sakate R, Pavan MA, Kobori RF, Gioria R, Yuki VA (2012) Avaliação de danos causados pelo Tomato severe rugose virus (ToSRV) em cultivares de pimentão. Summa Phytopathologica 38:87-89.

Rodríguez HB (2011) The role of chili in human nutrition. In: Torres HHP (Ed.) Chili: A key feature of independence and the Revolution. Cidade do México D.F. Herdez Foundation. pp. 2940.

Stanley J, Bisaro DM, Briddon RW, Brown JK, Fauquet CM, Harrison BD, Rybicki EP, Stenger DC (2005) Family Geminiviridae. In: Fauquet CM, Mayo MA, Maniloff J, Desselberger U, Ball LA (Eds.) VirusTaxonomy. VIIIth Report of the International Committee on Taxonomy of Viruses. San Diego CA. Elsevier Academic Press. pp. 301-326.

Vlot AC, Dempsey DA, Klessig D F (2009) Salicylic acid, a multifaceted hormone to combat disease. Annual Review of Phytopathology 47:177-206. 